\title{
Development of a Novel and Simple Electroanalytical Procedure for the Determination of Copper in Biofuel Employing a Sensor Based on Vulcan Functionalized with Carbazone
}

\author{
Tayane A. Freitas, ${ }^{a}$ Manoel J. A. Lima, ${ }^{a}$ Aldaléa L. B. Marques, ${ }^{b}$ Edmar P. Marques, ${ }^{a}$ \\ Rita C. S. Luz ${ }^{b}$ and Cicero W. B. Bezerra*,a \\ ${ }^{a}$ Departamento de Química and ${ }^{b}$ Departamento de Tecnologia Química, \\ Universidade Federal do Maranhão, 65080-805 São Luís-MA, Brazil
}

\begin{abstract}
A novel and simple electroanalytical method for the determination of $\mathrm{Cu}^{2+}$ in biodiesel samples by stripping voltammetric analysis was developed. The method employs a carbon paste electrode (CPE) modified with Vulcan carbon, previouly functionalized with carbazone (CBZ). The CPE/Vulcan-CBZ sensor promoted a significant increase in the analytical signal obtained from copper as compared to unmodified CPE, and the CPE modified with Vulcan carbon (CPE/ Vulcan). Vulcan-CBZ, Vulcan and CBZ materials were characterized by Fourier transform infrared spectroscopy (FTIR) technique. The electrochemical behavior of the sensor was evaluated using cyclic voltammetry $(\mathrm{CV})$ and square-wave anodic stripping voltammetric (SWASV) techniques. The CPE/Vulcan-CBZ modified electrode showed excellent response and was able to detect $\mathrm{Cu}^{2+}$ at nanomolar levels. The electrochemical method is based on preconcentration of $\mathrm{Cu}^{2+}$ ions on the CPE/Vulcan-CBZ at $0.35 \mathrm{~V} v s$. $\mathrm{Ag} / \mathrm{AgCl}$ (sat) in $0.2 \mathrm{~mol} \mathrm{~L}^{-1}$ ammonium sulfate solution $\left(\left(\mathrm{NH}_{4}\right)_{2} \mathrm{SO}_{4}\right), \mathrm{pH} 3.5$, during $120 \mathrm{~s}$, followed by subsequent chemical stripping. The analytical signal showed a linear response for $\mathrm{Cu}^{2+}$ concentrations in the range from 6 to $190 \mathrm{nmol} \mathrm{L}^{-1}(\mathrm{r}=0.998)$, with a detection limit of $1.2 \mathrm{nmol} \mathrm{L}^{-1}$. The sensor was successfully applied for the determination of $\mathrm{Cu}^{2+}$ in biodiesel and the average recovery varied between 97.0 and $102.8 \%$ for the soybean biodiesel samples and between 109.6 and $111.0 \%$ for the babassu biodiesel samples showing a good accuracy for the proposed method.
\end{abstract}

Keywords: biofuel, copper, voltammetric sensor, Vulcan carbon, carbazone

\section{Introduction}

The pursuit of alternative fuels has been acquiring prominence in the last decades. The replacement of fossil fuels has been motivated by environmental, economical and social factors, since society itself depends on its use. In this context, one alternative that has stood out is the use of biofuels, such as charcoal, alcohol, biogas and biodiesel..$^{1,2}$

Biodiesel is a renewable fuel produced either from vegetable sources (soybean, castor oil, palm oil, sunflower, among others) or from ethanol (from sugarcane) or methanol (which can be obtained from wood biomass). ${ }^{3}$ It is, therefore, a biodegradable, sustainable and environmentally friendly fuel. However, some metals, such as $\mathrm{Cu}, \mathrm{Fe}$, and $\mathrm{Ni}$, can be inserted in the production process with the catalysts, during transportation and storage. Furthermore, the presence of these metals, even

*e-mail: cwb.bezerra@ufma.br at trace levels, can promote the formation of gums and sediments that damage vehicle engines and promote the oxidation of biodiesel. ${ }^{4,5}$

Copper, iron and the effect of nickel on biodiesel's stability has been widely evaluated. Among these metals, copper is the most powerful catalyst in biodiesel's oxidation process. ${ }^{5}$ Therefore, the monitoring of the amount of copper is extremely important in this fuel for preventing undesirable variations in its physical state and properties, during its use or storage. ${ }^{5}$

In this context, it is opportune and necessary to develop novel sensitive and selective analytical methods for copper determination in biodiesel. Many studies have been conducted on the determination and monitoring of metals in fuels, employing spectroanalytical ${ }^{6-11}$ and electroanalytical ${ }^{12-17}$ techniques. The latter has been playing an important role, due to its high sensibility and precision, low cost of equipment and maintenance, and use of small quantities of samples and reagents. 
In the electroanalytical methods, the main reaction occurs at the electrode-solution interface, on which, all the versatility, efficiency and performance of the analytical methodology depends. However, unfavorable situations may occur in which the interaction of electrode with the sample causes loss, low signal or irreproducible measurements. ${ }^{18}$ Thus, it is necessary to develop materials that can act efficiently as electrode surfaces for the quantification of different species, with great selectivity, sensitivity and stability, similar to the case of metal ions.

Among the several types of carbon materials, the Vulcan $\mathrm{XC}-72 \mathrm{R}$ is mostly used as a support for fuel cells due to its high electrical conductivity, porous structure, large surface area and chemical reactivity. 19,20 This material has oxygenated surface groups that may be useful for the generation of thiosemicarbazones, which present important properties to form stable complexes with some metal cations..$^{21-25}$

This work describes the synthesis and application of the Vulcan-cabarzone composite (Vulcan-CBZ) for the determination of copper ions $\left(\mathrm{Cu}^{2+}\right)$ in complex samples, such as biodiesel, aiming to the development of a stable, sensitive and selective voltammetric sensor. Additionally, to the best of our knowledge, there is no report available that addresses the modification of Vulcan with tiosemicarbazide and its applications. The methodology was based on the use of a modified composite (Vulcan-CBZ) to increase the analytical signal, employing the square wave anodic redissolution (SWASV) technique for the analyte quantification.

\section{Experimental}

\section{Reagents and solutions}

For this research, all solutions were prepared using purified water (specific resistivity $>18.2 \mathrm{M} \Omega \mathrm{cm}$ at $25^{\circ} \mathrm{C}$ ). The chemicals used were of analytical grade (Merck, Aldrich and Vetec), such as: $\mathrm{HNO}_{3}, \mathrm{HCl}, \mathrm{K}_{3}\left[\mathrm{Fe}(\mathrm{CN})_{6}\right]$, $\mathrm{KCl},\left(\mathrm{NH}_{4}\right)_{2} \mathrm{SO}_{4}, \mathrm{KNO}_{3}, \mathrm{CH}_{3} \mathrm{COOH}, \mathrm{CH}_{3} \mathrm{COONa}, \mathrm{H}_{3} \mathrm{PO}_{4}$, $\mathrm{K}_{2} \mathrm{HPO}_{4}, \mathrm{H}_{2} \mathrm{C}_{2} \mathrm{O}_{4}, \mathrm{Na}_{2} \mathrm{C}_{2} \mathrm{O}_{4}, \mathrm{H}_{2} \mathrm{SO}_{4}, \mathrm{NH}_{4} \mathrm{OH}, \mathrm{C}_{2} \mathrm{H}_{5} \mathrm{OH}$, $\mathrm{CuSO}_{4} .5 \mathrm{H}_{2} \mathrm{O}, \mathrm{N}_{3} \mathrm{H}_{5} \mathrm{~S}$ (thiosemicarbazide, $\mathrm{CB}$ ), graphite powder and mineral oil. The standard metal solutions $\left(\mathrm{Cu}^{2+}\right.$, $\mathrm{Pb}^{2+}, \mathrm{Co}^{2+}, \mathrm{Cd}^{2+}$ and $\left.\mathrm{Zn}^{2+}\right)$ were prepared from a stock solution of $1000 \mathrm{mg} \mathrm{L}^{-1}$ (Titrisol, Merck). The Vulcan XC-72R came from Cabot Corporation. The vegetable oils used (babassu and soybean) were purchased from a local market.

\section{Equipment and accessories}

In this research, Fourier transform infrared (FTIR) spectra were obtained using a Shimadzu IR spectrophotometer, model Prestige-21, in the region between $4000-400 \mathrm{~cm}^{-1}$ with the ATR (attenuated total reflectance) accessory, employing $1 \% \mathrm{KBr}$ pellets. The $\mathrm{pH}$ measurements were performed using a Quimis digital $\mathrm{pH}$ meter, model Q400A. The electrochemical measurements were performed with an Autolab voltammetric analyzer (Metrohm), model PGSTAT 302, coupled with an Intel Celeron D computer with a GPES software.

The electrochemical measurements were carried out in a three-electrode system composed of a carbon paste electrode (CPE) as working electrode, Pt wire as counter electrode, and $\mathrm{Ag} / \mathrm{AgCl}$ (saturated) as reference electrode. The measurements were carried out using $10 \mathrm{~mL}$ of the supporting electrolyte. The working electrode was a CPE modified with Vulcan-CBZ with electroactive area of the electrode of ca. $0.265 \mathrm{~cm}^{2}$, estimated according to RandlesSevcik equation. ${ }^{17}$ Additional equipment employed was a LAB 1000 centrifuge, model DM0412, and an ultrasound Quimis, model Q 335 D.

Synthesis of the composite Vulcan-carbazone (Vulcan-CBZ)

Vulcan-CBZ composite was prepared based on the condensation reaction of thiosemicarbazide (CB) and carbonyl groups at the Vulcan support. About $500 \mathrm{mg}$ of Vulcan XC-72R were oxidized by $\mathrm{HNO}_{3}\left(1.0 \mathrm{~mol} \mathrm{~L}{ }^{-1}\right.$, $50 \mathrm{~mL}$ ) under reflux condition for $3 \mathrm{~h}$. Consequently, the obtained product was filtered and successively washed with water until $\mathrm{pH}$ remained $\mathrm{ca}$. 6 . It was then oven-dried at $70^{\circ} \mathrm{C}$. The anchoring of $\mathrm{CB}$ in the funtionalized Vulcan was performed by the reaction between the previously oxidized support $(100 \mathrm{mg}$, corresponding to $0.5970 \mathrm{mmol}$ of the surface acid groups) and the CB (163 mg, $1.791 \mathrm{mmol}$ ), in slightly acidified ethanolic medium $(\mathrm{HCl})$, having kept under reflux conditions for $2 \mathrm{~h}$. The synthesized material, designated as Vulcan-carbazone (Vulcan-CBZ), was ovendried at $50{ }^{\circ} \mathrm{C}$ and kept under vacuum atmosphere.

Preparation of the working electrode and electrochemical measurements

The working electrode body was constructed by pressing a copper rod inside of a pipette tip and leaving a hole at the surface for packaging the carbon paste, which was prepared by thoroughly mixing graphite powder, Vulcan-CBZ and mineral oil, in a mortar with pestle. The working electrode was smoothed later on, using a clean paper (A4) until it revealed a shiny appearance.

The analytical procedure was optimized using the univariate method and the square wave anodic stripping voltammetry technique (SWASV). The main experimental 
variables studied were: $(i)$ carbon paste composition: $25 \%$ $(\mathrm{m} / \mathrm{m})$ mineral oil, 2.5 to $15.0 \%(\mathrm{~m} / \mathrm{m})$ of Vulcan-CBZ and 72.5 to $60 \%$ of graphite; (ii) supporting electrolyte: $0.1 \mathrm{~mol} \mathrm{~L}^{-1}$ $\left(\mathrm{NH}_{4}\right)_{2} \mathrm{SO}_{4}, \mathrm{KNO}_{3}, \mathrm{CH}_{3} \mathrm{COONa} / \mathrm{CH}_{3} \mathrm{COOH}, \mathrm{H}_{3} \mathrm{PO}_{4} / \mathrm{K}_{2} \mathrm{HPO}_{4}$ and $\mathrm{H}_{2} \mathrm{C}_{2} \mathrm{O}_{4} / \mathrm{Na}_{2} \mathrm{C}_{2} \mathrm{O}_{4}$; (iii) supporting electrolyte concentration: 0.05 to $0.2 \mathrm{~mol} \mathrm{~L}^{-1}$ and (iv) $\mathrm{pH}$ range: 2.5 to 7.0. The modification of the $\mathrm{CPE}$ with $\mathrm{CB}$ was made only by mixing $5 \% \mathrm{CB}$ with $70 \%$ grafite and $25 \%$ nujol oil. In addition, the following SWASV operational parameters were studied: deposition potential $\left(\mathrm{E}_{\mathrm{dep}}\right)$, deposition time $\left(\mathrm{t}_{\mathrm{dep}}\right)$ and frequency (f).

\section{Sample preparation and analysis}

In this work, biodiesel samples were obtained via methylic route, and soybean (A) and babassu (B) oils were used as vegetable oil sources. Moreover, samples were prepared according to the procedure described by Freitas et al. ${ }^{26}$ with minor modifications. A total of $0.2 \mathrm{~mL}$ of biodiesel samples were treated with $1.9 \mathrm{~mL}$ of $\mathrm{HCl} 37 \%$ $(\mathrm{m} / \mathrm{v})$ and $1.9 \mathrm{~mL}$ of $30 \% \mathrm{H}_{2} \mathrm{O}_{2}(\mathrm{~m} / \mathrm{v})$; under ultrasonic conditions for $30 \mathrm{~min}$. Then the samples were centrifuged for $10 \mathrm{~min}$ at $2000 \mathrm{rpm}$, from which an aliquot of $0.2 \mathrm{~mL}$ of the supernatant was withdrawn and added to the supporting electrolyte.

\section{Results and Discussion}

\section{Characterization of materials}

The FTIR spectra of the Vulcan, Vulcan-carbazone (Vulcan-CBZ) and the thiosemicarbazine in its free-form (CB) are shown in Figure S1 (Supplementary Information (SI) section). The Vulcan material (Figure S1a) shows a broad peak in the range of $3500-3200 \mathrm{~cm}^{-1}$ which corresponds to the vibration of stretching and bending of $\mathrm{OH}$ groups. There is a little contribution of: (i) symmetrical and anti-symmetrical $\mathrm{CH}_{2}$ stretching vibrations in the $2900-2800 \mathrm{~cm}^{-1}$ region; and (ii) the peak at $1714 \mathrm{~cm}^{-1}$ resulting from the stretching of the carbonyl bond of the $\mathrm{COOH}$ group. ${ }^{27}$ Also, in the medium frequency region, there is a broad band in the range of 1665 $1500 \mathrm{~cm}^{-1}$ due to the contribution of the angular deformation of the $\mathrm{OH}$ group conjugated with the $\mathrm{CO}$ stretch. Finally, the peaks at 1352 and $1230 \mathrm{~cm}^{-1}$ correspond to the $\mathrm{C}-\mathrm{C}$ and $\mathrm{C}-\mathrm{OH}$ stretching vibration of carboxylic groups. ${ }^{27}$

Relating to Vulcan-CBZ spectrum (Figure S1b) the presence of characteristic stretches of thiosemicarbazide functional groups can be clearly observed (Figure S1c): 22,28,29 $v(\mathrm{C}=\mathrm{S}) 840-730 \mathrm{~cm}^{-1}, v(\mathrm{~N}-\mathrm{N}) 1037-840 \mathrm{~cm}^{-1}$ and $v(\mathrm{~N}-\mathrm{H})$ $3368-3175 \mathrm{~cm}^{-1}$. It is also noted that the peak assigned to $\mathrm{N}-\mathrm{H}$ centered at $3363 \mathrm{~cm}^{-1}$ underwent a slight change. A peak between $1562-1546 \mathrm{~cm}^{-1}$ is further observed which corresponds to the absorption of the $\mathrm{C}=\mathrm{N}$ bond, and the bond between support (Vulcan) and ligand (CB). It indicates that the Vulcan-CBZ composite was formed, as suggested by the following schematic condensation reaction (equation 1):

$$
\begin{aligned}
& \operatorname{Vulcan}(\mathrm{C}=\mathrm{O})+\mathrm{H}_{2} \mathrm{NNHC}(=\mathrm{S}) \mathrm{NH}_{2} \rightarrow \\
& \qquad \operatorname{Vulcan}\left(\mathrm{C}=\mathrm{NNHC}(=\mathrm{S}) \mathrm{NH}_{2}\right)+\mathrm{H}_{2} \mathrm{O}
\end{aligned}
$$

Electrochemical behavior of Vulcan-CBZ in the presence of $\mathrm{Cu}^{2+}$

In order to evaluate the viability of the VulcanCBZ which acts as an electrochemical sensor for the determination of $\mathrm{Cu}^{2+}$ ions, preliminary records of SWASV were carried out at different ion concentration of $\mathrm{Cu}^{2+}$, in the presence of unmodified carbon paste electrode (unmodified $\mathrm{CPE}$ ); the carbon paste electrodes modified with Vulcan (CPE/Vulcan); and Vulcan-carbazone (CPE/Vulcan-CBZ) (Figure 1). The initially established experimental conditions were as following: $0.1 \mathrm{~mol} \mathrm{~L}^{-1}\left(\mathrm{NH}_{4}\right)_{2} \mathrm{SO}_{4}$ as electrolyte, $\mathrm{pH}$ 3.5 , carbon-paste composition of graphite powder $(70 \%)$, modifier $(5 \%)$ and mineral oil (25\%).

As observed from Figure 1a, higher analytical signal was achieved by using Vulcan-CBZ (black solid line). In fact, this electrode increased the electroanalytical response by five times when compared to the other tested electrodes, indicating that it played an important role in the electrochemical detection of $\mathrm{Cu}^{2+}$. It can be explained due to the presence of donor atoms ( $\mathrm{S}$ and $\mathrm{N}$ ) on the composite surface, which allow the formation of the metal ion complexes. Indeed, thiosemicarbazones are able to form stable complexes with some metallic cations, such as zinc, copper and iron..$^{21,22}$

The analytical curves obtained (Figure 1b) showed a good linear range for all electrodes. However, special sensitivity was reached while using CPE/Vulcan-CBZ $\left(0.18 \mu \mathrm{A} \mathrm{nmol}{ }^{-1} \mathrm{~L}\right)$ in comparison to CPE/Vulcan $\left(0.04 \mu \mathrm{A} \mathrm{nmol}{ }^{-1} \mathrm{~L}\right)$ and unmodified $\mathrm{CPE}\left(0.03 \mu \mathrm{A} \mathrm{nmol}^{-1} \mathrm{~L}\right)$. Additionally, considering the coordination capacity of the $\mathrm{CB}$ ligand, construction of an analytical curve with only $\mathrm{CPE} / \mathrm{CB}$ was attempted. It was observed that the electrode did not provide a linear response in the determination of $\mathrm{Cu}^{2+}$ ions in the concentration range studied (data not shown). We believe that the non-linear behavior may be associated to the instability of $\mathrm{CB}$ in the paste. Hence, the use of Vulcan along with carbazone has proved to be an excellent alternative for the detection/quantification of copper with high sensitivity, and therefore, it was used in subsequent studies. 

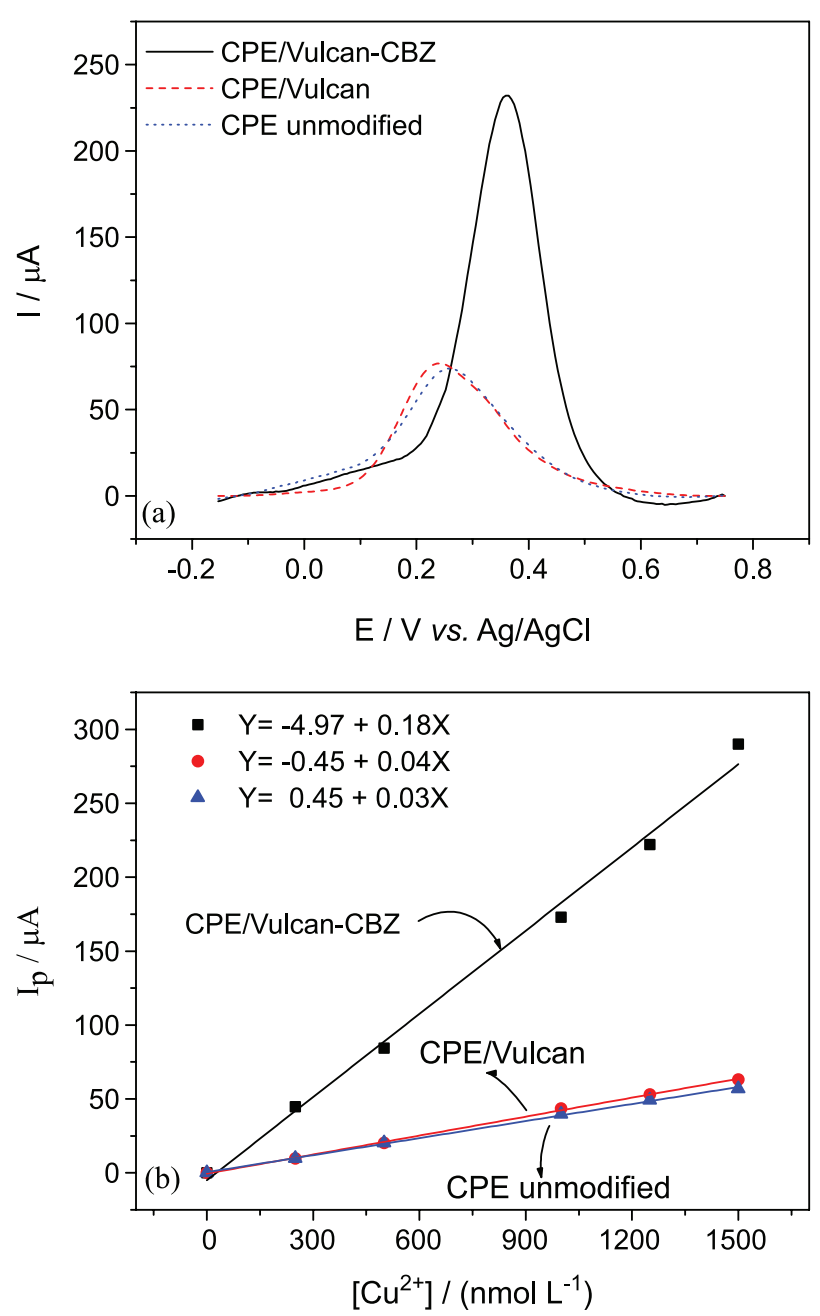

Figure 1. (a) Electrode response: CPE/Vulcan-CBZ (black solid voltammogram); $\mathrm{CPE} /$ Vulcan (red dashed voltammogram) and unmodified CPE (blue dotted voltammogram) to $1.0 \mu \mathrm{mol} \mathrm{L}^{-1}$ of $\mathrm{Cu}^{2+}$; (b) calibration curves obtained with materials used in (a) (CPE/Vulcan-CBZ, $\mathrm{CPE} /$ Vulcan, unmodified CPE) at different concentrations of $\mathrm{Cu}^{2+}: 250$; 500; 750; 1000; 1250 and $1500 \mathrm{nmol} \mathrm{L}^{-1}$. Experiments were performed with the SWASV technique in the following experimental conditions: $\mathrm{E}_{\text {dep }}=-0.5 \mathrm{~V}, \mathrm{t}_{\text {dep }}=105 \mathrm{~s}, \mathrm{f}=60 \mathrm{~Hz}$ and $\mathrm{A}_{\mathrm{p}}=0.025 \mathrm{~V}$.

\section{Influence of scan rate}

In this work, the cyclic voltammetry of $\mathrm{Cu}^{2+}$ in $0.1 \mathrm{~mol} \mathrm{~L}^{-1}\left(\mathrm{NH}_{4}\right)_{2} \mathrm{SO}_{4}, \mathrm{pH} 3.5$, was investigated at $\mathrm{CPE} /$ Vulcan-CBZ electrode within the potential window of -0.75 to $0.75 \mathrm{~V}$ and recorded at different scan rates (Figure 2a). The carbon-paste composition was: $70 \%$ graphite powder, 5\% Vulcan-CBZ and 25\% mineral oil. An anodic sweep with an initial potential of $-0.75 \mathrm{~V}$ shows one oxidation peak at $0.29 \mathrm{~V}$, followed by two reduction peaks at 0.01 and $-0.36 \mathrm{~V}$ in the reverse sweep. The appearance of two reduction peaks can be associated with the presence of more than one coordination site on the electrode for $\mathrm{Cu}^{2+} .30$

The influence of scan rate on the oxidation of copper was evaluated from 10 to $100 \mathrm{mV} \mathrm{s}^{-1}$. It can be found that
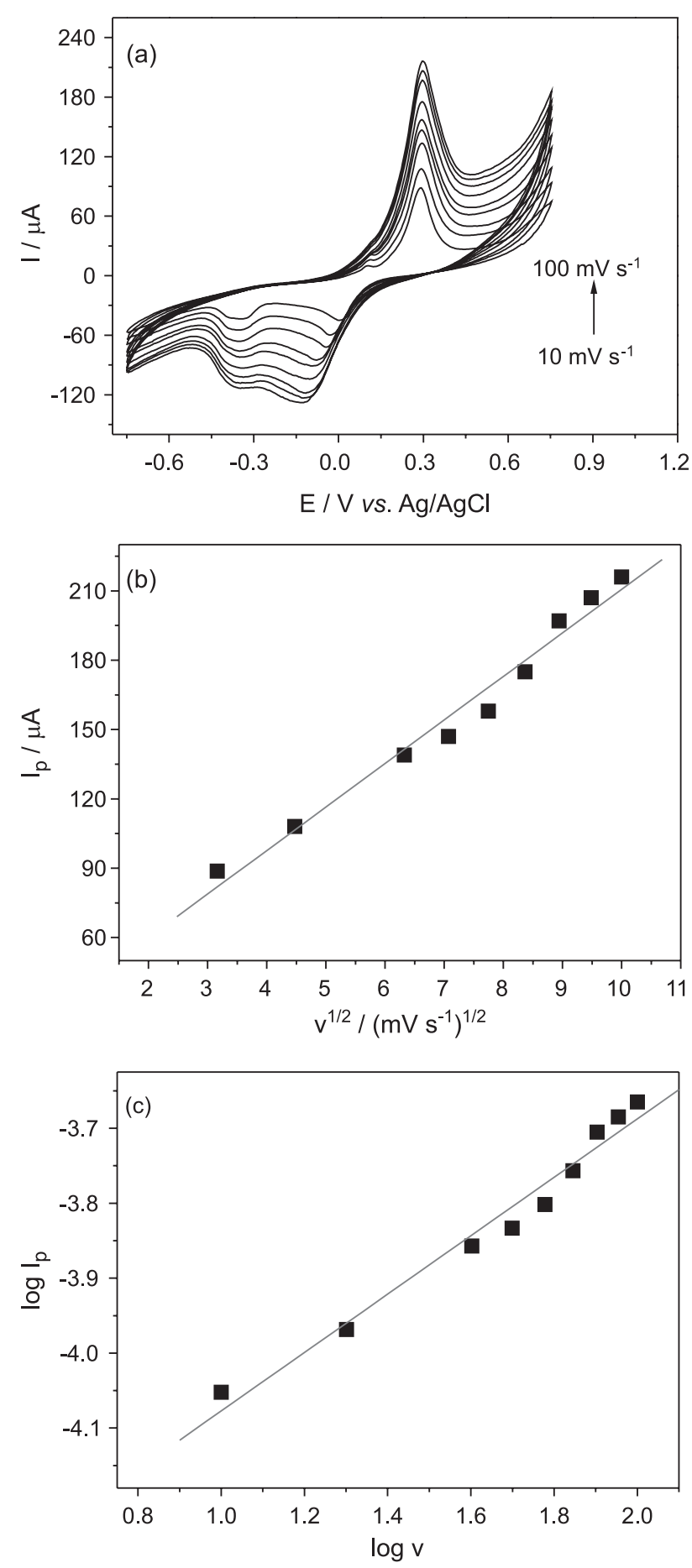

Figure 2. (a) Cyclic voltammograms recorded at scan rates between 10 and $100 \mathrm{mV} \mathrm{s}^{-1}$. Relation between (b) anodic peak current $\left(\mathrm{I}_{\mathrm{p}}\right)$ versus $\mathrm{v}^{1 / 2}$ and (c) $\log$ anodic peak current $\left(\mathrm{I}_{\mathrm{p}}\right)$ versus $\log \mathrm{v}$ (scan rate). Experiments were carried in $0.1 \mathrm{~mol} \mathrm{~L}^{-1}\left(\mathrm{NH}_{4}\right)_{2} \mathrm{SO}_{4}, \mathrm{pH} 3.5$, containg $1 \mathrm{mmol} \mathrm{L}^{-1} \mathrm{Cu}^{2+}$.

both cathodic and anodic peak current goes higher with the increase of scan rate. It is further observed that both peak positions are slightly shifted towards the negative potential (cathodic peak) and positive direction (anodic peak) (Figure 2a). In addition to dependence of peak current with scan rate, the ratio $i_{\mathrm{pa}} i_{\mathrm{pc}}\left(\mathrm{i}_{\mathrm{pa}}\right.$ and $\mathrm{i}_{\mathrm{pc}}$ are the anodic and 
cathodic peak current, respectively) is greater than unity, suggesting a non-reversible process.

The experimental results indicate that there is a linear variation of peak currents with square root of scan rate $\left(I_{p}(\mu A)=22.3+18.8 v^{1 / 2}, r=0.988\right)$, suggesting that the process is diffusion controlled (Figure 2b). Furthermore, the plot of log peak current vs. log scan rate showed a straight line (Figure 2c), its slope value is below $0.5\left(\log \mathrm{I}_{\mathrm{p}}=-3.3+0.39 \log \mathrm{v}, \mathrm{r}=0.986\right)$ which confirms that the overall reaction is controlled by a diffusional process. $^{31,32}$

\section{Optimization of the experimental and operational conditions of the SWASV technique}

In order to verify the effect of the carbon paste composition in the voltammetric response of the electrodes, analytical curves were constructed by SWASV using the following composition of Vulcan-CBZ:graphite powder $(\% \mathrm{~m} / \mathrm{m}): 2.5: 72.5 ; 5: 70 ; 7.5: 67.5 ; 10: 65 ; 12.5: 62.5$; $15: 60$, and $25 \% \mathrm{~m} / \mathrm{m}$ of mineral oil, on electrodes. Table 1 summarizes the analytical figure of merits obtained for each curve. The anodic peak current increased up to $5 \%(\mathrm{~m} / \mathrm{m})$ with the amount of Vulcan-CBZ in the paste, and decreased when more modifier is used in the electrode preparation. This electrode provided better results regarding to some of the analytical parameters, such as the linear correlation coefficient and sensitivity, and was employed in the subsequent studies.

Also to assess the best sensor response, another evaluated parameter was the nature of the supporting electrolyte. The electrolytic solutions studied were ammonium sulfate, potassium nitrate, phosphate buffer, acetate buffer and oxalate buffer, all in the concentration of $0.1 \mathrm{~mol} \mathrm{~L}^{-1}$ ( $\left.\mathrm{pH} 3.5\right)$, containing $1.0 \mu \mathrm{mol} \mathrm{L}{ }^{-1}$ of copper in the electrochemical cell. The most defined peaks and maximum anodic currents were found when the $\left(\mathrm{NH}_{4}\right)_{2} \mathrm{SO}_{4}$ solution was used, followed by the solutions of $\mathrm{KNO}_{3}$, oxalate buffer, phosphate buffer and acetate buffer (Figure 3a), showing that there is a significant contribution of the ionic species from the solution, in the electrodeposition of $\mathrm{Cu}^{2+}$ on the electrode surface. Thus, the ammonium sulfate solution was chosen as the supporting electrolyte. Regarding the concentration of solution (Figure $3 b$ ), the increase in current variation occurred in the range of 0.05 to $0.4 \mathrm{~mol} \mathrm{~L}^{-1}$. This fact was expected, since the conductivity of the solution increases with the concentration of the electrolyte. ${ }^{33}$ However, at the concentration between 0.2 and $0.4 \mathrm{~mol} \mathrm{~L}^{-1}$, no significant variation in the analytical signal was observed. Thus, the $0.2 \mathrm{~mol} \mathrm{~L}^{-1}$ concentration of this electrolyte was chosen for the subsequent analysis.

The effect of $\mathrm{pH}$ has also been investigated in the range of 2.5 to 7.0 (Figure $3 \mathrm{c}$ ). The $\mathrm{pH}$ of the solution directly affected the voltammetric response of copper over the CPE/Vulcan-CBZ. A pronounced increase of the peak current in the $\mathrm{pH}$ range of 2.5 and 3.5 is observed along with a decrease of peak current between 3.5 and 5.0. According to literature, ${ }^{34}$ this result can be justified by the fact that the $\mathrm{Cu}^{2+}$ ions undergo partial or total hydrolysis at $\mathrm{pH}$ higher than 3.5 , decreasing the free $\mathrm{Cu}^{2+}$ concentration, and subsequently decreasing the interaction with the electrode. Another suggestion is that, the decrease of the peak currents above pH 3.5 occurs due to lower stability of the Vulcan-CBZ material in $\mathrm{pH}$ values above 3.5 , which makes it difficult the interaction between the $\mathrm{Cu}^{2+}$ ions and the electrode surface (CPE/Vulcan-CBZ). Based on these results, $\mathrm{pH} 3.5$ was chosen to perform the other analysis.

Additionally, the effect of $\mathrm{pH}$ on the redox potential of $\mathrm{Cu}^{2+}$ was also evaluated using CPE/Vulcan-CBZ. The experimental results indicate that $\mathrm{pH}$ has a significant influence on copper peak potential values. According to Figure $3 \mathrm{~d}$, the peak potential $\left(\mathrm{E}_{\mathrm{p}}\right)$ of the copper ions shifted to more negative potentials, with an increase in the $\mathrm{pH}$ value from 2.5 to 4.0 . The $\mathrm{E}_{\mathrm{p}}$ values changed linearly with changes in the $\mathrm{pH}$ values, showing an inclination of $-0.047 \mathrm{~V} \mathrm{pH}^{-1}$. This inclination is close to that expected for an electrode reaction involving 2 protons and 2 electrons

Table 1. Optimization of the carbon paste ingredients. Analytical curves obtained by SWASV with the following concentrations of $\mathrm{Cu}^{2+}: 0.25 ; 0.5 ; 0.75$; $1.0 ; 1.25$ and $1.5 \mu \mathrm{mol} \mathrm{L}{ }^{-1}$. $\mathrm{E}_{\text {dep }}=-0.5 \mathrm{~V}, \mathrm{t}_{\text {dep }}=105 \mathrm{~s}, \mathrm{f}=60 \mathrm{~Hz}$ and $\mathrm{A}_{\mathrm{p}}=0.025 \mathrm{~V}$

\begin{tabular}{|c|c|c|c|c|c|}
\hline \multirow{2}{*}{ No. } & \multicolumn{3}{|c|}{ Composition $(\%, \mathrm{~m} / \mathrm{m})$} & \multicolumn{2}{|c|}{ Performance } \\
\hline & Graphite powder & Vulcan-CBZ & Paraffin oil & $\mathrm{r}$ & Slope / $\left(\mu \mathrm{A} n m o l L^{-1}\right)$ \\
\hline 1 & 72.5 & 2.5 & & 0.977 & 0.05 \\
\hline 2 & 70.0 & 5.0 & & 0.997 & 0.19 \\
\hline 3 & 67.5 & 7.5 & 25 & 0.992 & 0.13 \\
\hline 4 & 65.0 & 10.0 & & 0.976 & 0.09 \\
\hline 5 & 62.5 & 12.5 & & 0.996 & 0.08 \\
\hline
\end{tabular}

SWASV: square wave anodic stripping voltammetry; Vulcan-CBZ: Vulcan-carbazone. 

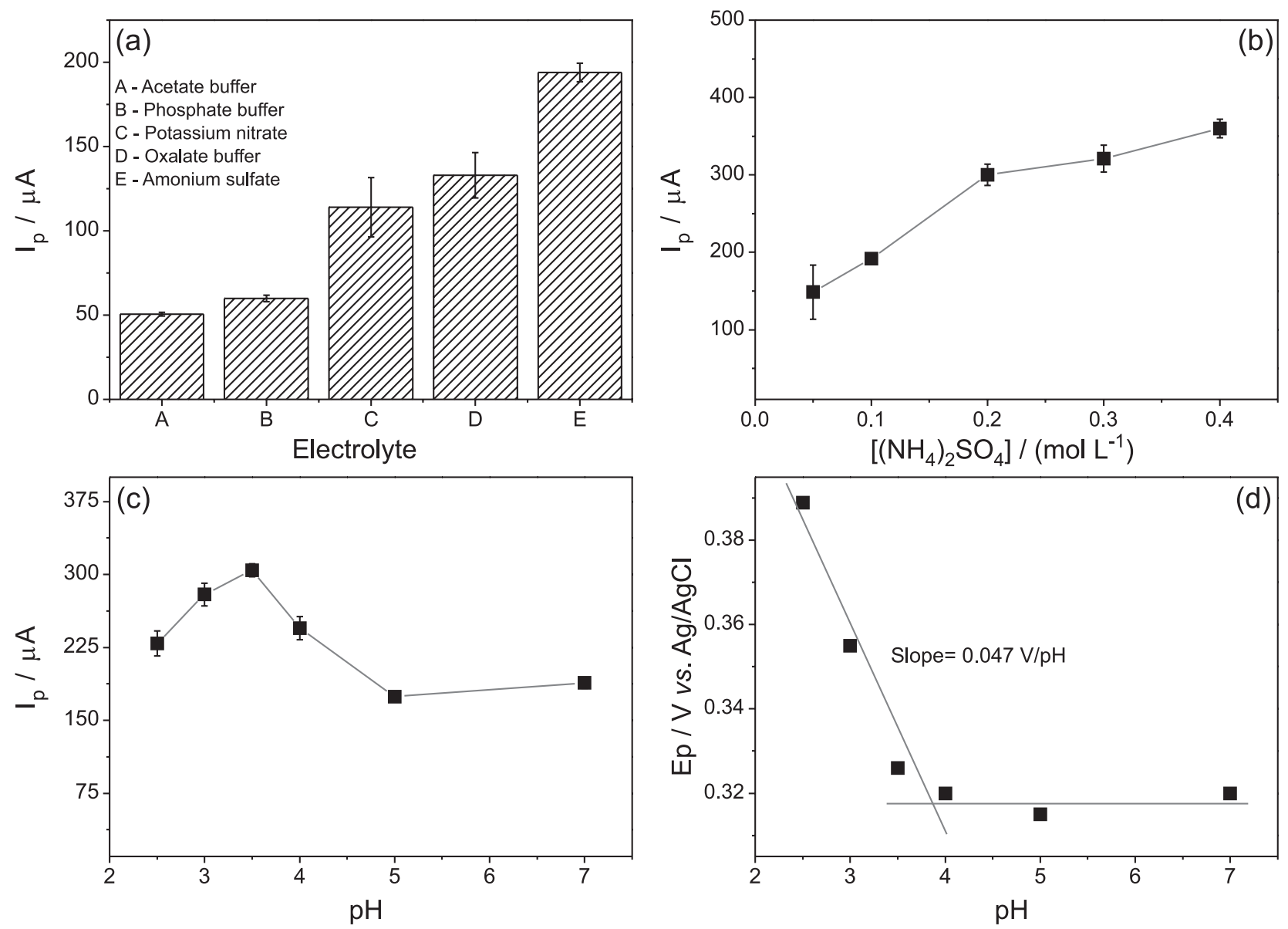

Figure 3. Effect of the: (a) nature of the supporting electrolyte $\left(0.1 \mathrm{~mol} \mathrm{~L}^{-1}, \mathrm{pH} 3.5\right)$; (b) supporting electrolyte concentration $(0.05,0.1,0.2,0.3$ and $0.4 \mathrm{~mol} \mathrm{~L}^{-1}(\mathrm{pH} 3.5)$; (c) and (d) $\mathrm{pH}$ of the electrolytic solution on the voltammetric $\mathrm{Cu}^{2+}$ response. Experimental conditions: $\left[\mathrm{Cu}^{2+}\right]=1.0 \mu \mathrm{mol} \mathrm{L}^{-1}$. $\mathrm{E}_{\text {dep }}=-0.5 \mathrm{~V} ; \mathrm{t}_{\text {dep }}=105 \mathrm{~s}, \mathrm{~A}_{\mathrm{p}}=0.025 \mathrm{~V}$ and $\mathrm{f}=60 \mathrm{~Hz}$.

$\left(0.059 \mathrm{~V} \mathrm{pH}^{-1}\right.$ at $\left.25^{\circ} \mathrm{C}\right)$. Thus, $\mathrm{Cu}^{2+}$ ions are accumulated on the electrode as a complex, since bonding takes place between the metal ions and CBZ ligand. Hereafter, this complex is reduced to generate $\mathrm{Cu}^{0}$ and a free $\mathrm{CBZ}$ ligand $\left(\mathrm{Cu}^{2+}\right.$-Vulcan-CBZ $+2 \mathrm{H}^{+}+2 \mathrm{e}^{-} \rightleftarrows \mathrm{Cu}^{0}+$ Vulcan-CBZ $)$. Subsequently, the $\mathrm{Cu}^{0}$ is reoxidized to $\mathrm{Cu}^{2+}$, and it is at this redissolution stage that the final determination is as following: $\mathrm{Cu}^{0}+$ Vulcan-CBZ $\rightleftarrows \mathrm{Cu}^{2+}-$ Vulcan-CBZ $+2 \mathrm{H}^{+}+2 \mathrm{e}^{-}$.

The operational parameters of the SWASV technique: deposition potential $\left(\mathrm{E}_{\mathrm{dep}}\right)$, deposition time $\left(\mathrm{t}_{\mathrm{dep}}\right)$ and frequency (f), were also studied, setting the amplitude $\left(A_{p}\right)$ at $0.025 \mathrm{~V}$ and the equilibrium time $\left(\mathrm{t}_{\mathrm{eq}}\right)$ as $15 \mathrm{~s}$. Figure 4 shows the influence of these parameters on the analytical signal of copper. According to the obtained results, it is observed that the highest peak currents for the analyte were reached under the following conditions: $\mathrm{E}_{\text {dep }}=-0.5 \mathrm{~V}$; $\mathrm{t}_{\text {dep }}=120 \mathrm{~s} ; \mathrm{f}=60 \mathrm{~Hz} ; \mathrm{A}_{\mathrm{p}}=0.025 \mathrm{~V}$. Therefore, such conditions were used for the construction of the analytical curve for copper. The experiments were conducted in the presence of $150 \mathrm{nmol} \mathrm{L}^{-1}$ of $\mathrm{Cu}^{2+}$ ions in $0.2 \mathrm{~mol} \mathrm{~L}^{-1}$ of $\left(\mathrm{NH}_{4}\right)_{2} \mathrm{SO}_{4}, \mathrm{pH} 3.5$.

\section{Analytical characterization of the sensor}

Figure 5 is the analytical curve for the determination of $\mathrm{Cu}^{2+}$ ions in the biodiesel samples under optimized conditions. A linear range from 6 to $190 \mathrm{nmol} \mathrm{L}^{-1}$ is observed, with the following equation: $\mathrm{I}_{\mathrm{p}}(\mu \mathrm{A})=1.1+2.0\left[\mathrm{Cu}^{2+}\right]\left(\mathrm{nmol} \mathrm{L}^{-1}\right)$, $(\mathrm{r}=0.998, \mathrm{n}=9)$. The limit of detection (LOD) and quantification (LOQ) were estimated as 1.2 and $4 \mathrm{nmol} \mathrm{L}^{-1}$, respectively. These values were calculated, using the following equations: $\mathrm{LOD}=(3 \times \mathrm{SD}) / \mathrm{b}$ and $\mathrm{LOQ}=(10 \times \mathrm{SD}) / \mathrm{b}$, where SD is the standard deviation taken for ten measures of the blank $\left(0.80 \times 10^{-6}\right)$ and $b$ is the value for the angular coefficient of the analytical curve.

\section{Study of the sensor selectivity}

The influence of possible interferents, such as $\mathrm{Pb}^{2+}$, $\mathrm{Co}^{2+}, \mathrm{Cd}^{2+}$ and $\mathrm{Zn}^{2+}$ was also investigated by SWASV, in the optimized experimental conditions. In this sense, five analytical curves for $\mathrm{Cu}^{2+}$ were obtained at the concentration range of 6 to $30 \mathrm{nmol} \mathrm{L}^{-1}$ in the absence 

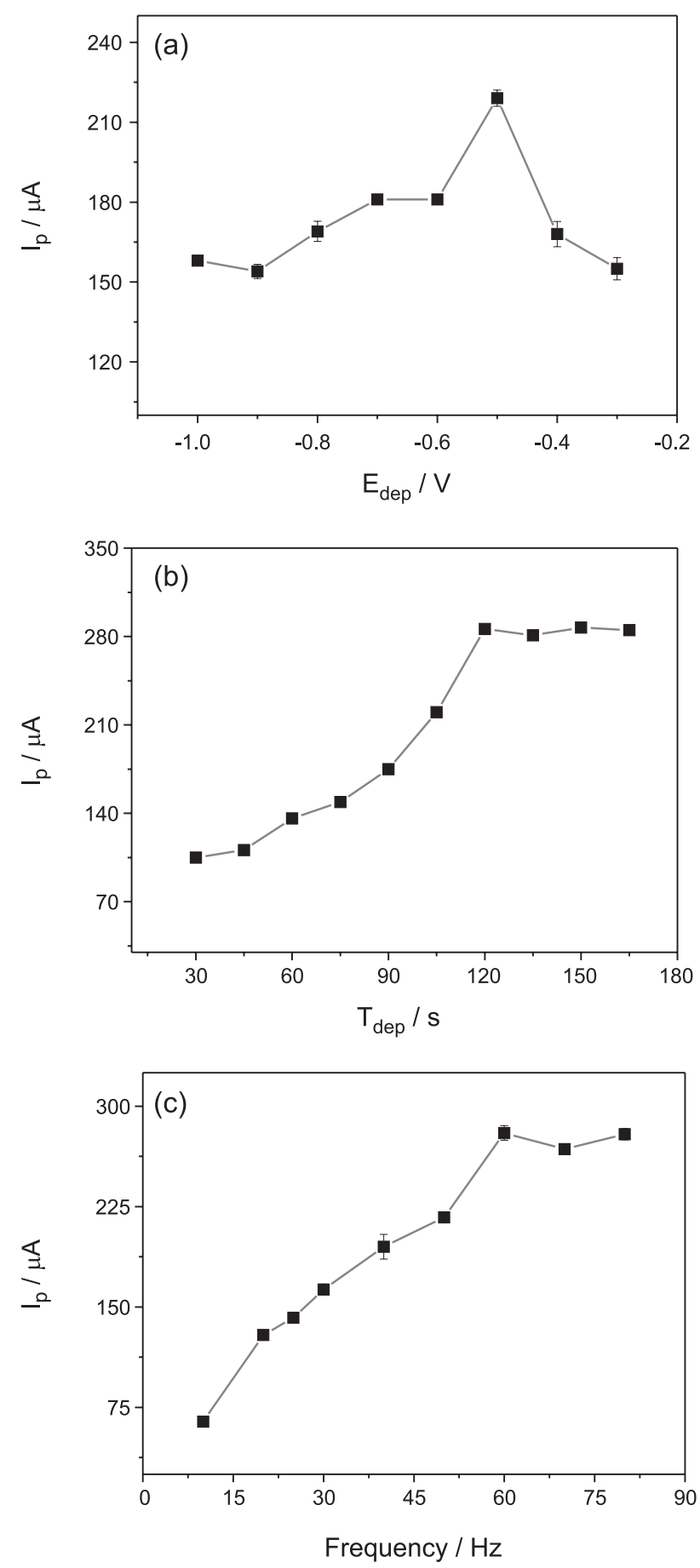

Figure 4. Optimization of the analytical SWASV parameters for $\mathrm{Cu}^{2+}$ ion $\left(150 \mathrm{nmol} \mathrm{L}^{-1}\right)$ determination: (a) $\mathrm{E}_{\text {dep }}$ using a $\mathrm{t}_{\text {dep }}=105 \mathrm{~s}, \mathrm{~A}_{\mathrm{p}}=0.025 \mathrm{~V}$ and $\mathrm{f}=60 \mathrm{~Hz}$, and (b) $\mathrm{t}_{\text {dep }}$ using an $\mathrm{E}_{\text {dep }}=-0.5 \mathrm{~V}$; and (c) frequency with $\mathrm{E}_{\mathrm{dep}}=-0.5 \mathrm{~V}, \mathrm{t}_{\mathrm{dep}}=120 \mathrm{~s}$.

(Figure 6, curve a) and presence of the interferents (Figure 6, curves b, c, d, and e). Based on these results, it was observed that the sensitivity of the Vulcan-CBZbased sensor for the copper ions in absence and presence of foreign ions were similar, confirming the good interaction of the modified electrode with the analyte

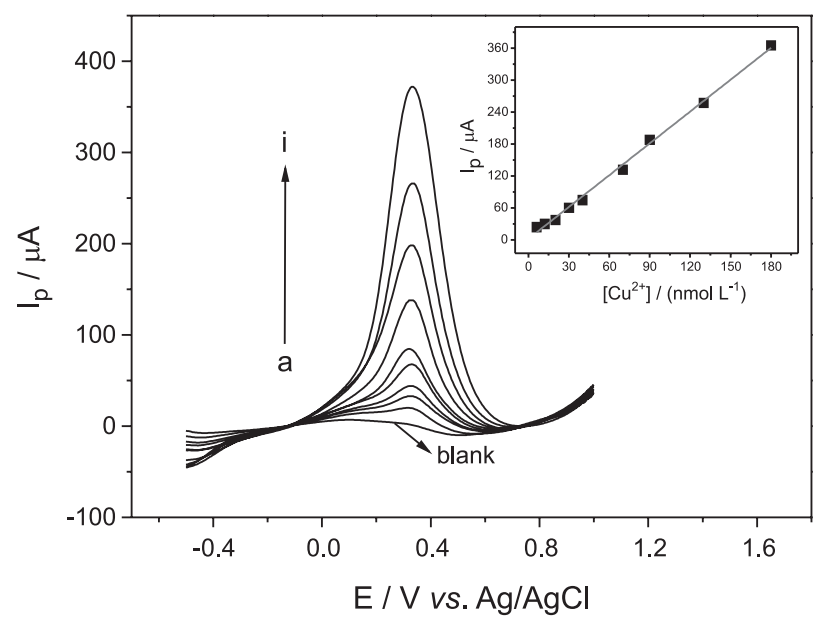

Figure 5. SW anodic redissolution voltammograms for various concentration of $\mathrm{Cu}^{2+}$ : (a) 6; (b) 12; (c) 20; (d) 30; (e) 40; (f) 70; (g) 90; (h) 130.0; and (i) $190 \mathrm{nmol} \mathrm{L}^{-1}$. Insert: analytical curve for copper. Experiments conducted in $0.2 \mathrm{~mol} \mathrm{~L}^{-1}$ solution $\left(\mathrm{NH}_{4}\right)_{2} \mathrm{SO}_{4}, \mathrm{pH} 3.5$. $\mathrm{E}_{\text {dep }}=-0.5 \mathrm{~V} ; \mathrm{t}_{\text {dep }}=120 \mathrm{~s} ; \mathrm{f}=60 \mathrm{~Hz} ; \mathrm{A}_{\mathrm{p}}=0.025 \mathrm{~V}$ and $\mathrm{t}_{\mathrm{eq}}=15 \mathrm{~s}$.

of interest $\left(\mathrm{Cu}^{2+}\right)$. Moreover, although there is a small variation of the sensitivity for the determination of the copper, the shift of the sensitivity for determination of the analyte of interest in presence of foreign species was lower than $7 \%$ when compared to sensitivity of the sensor for the determination of the analyte in the absence of each interfering species. These results suggest that these ions do not significantly interfere in the determination of copper. Furthermore, it is also important to emphasize that the standard addition method is a very reliable way to minimize the effect of the analyzed matrix. Finally, it can be said that the proposed sensor presents, besides a great sensitivity, an excellent selectivity for the developed system.

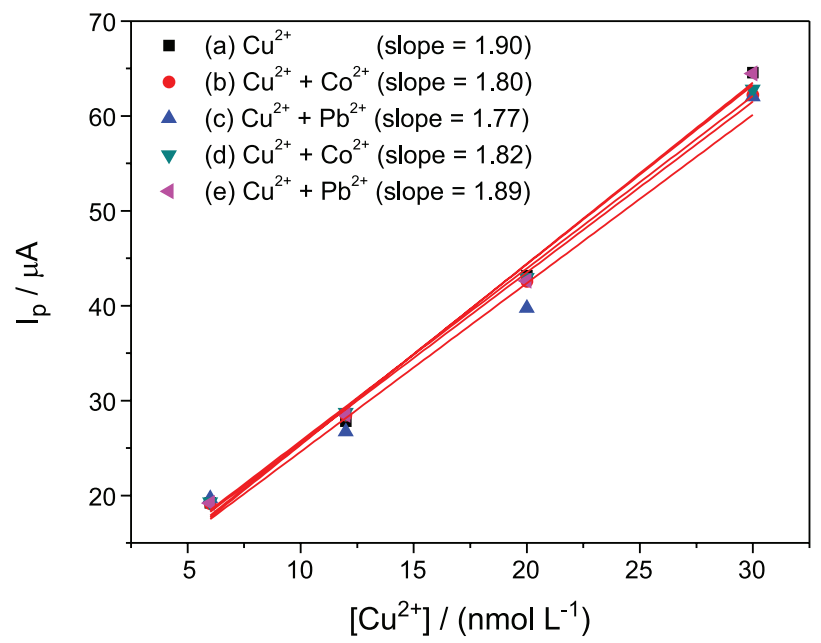

Figure 6. Analytical curves for copper ions in absence (a) and presence of possible interferents (b, c, d, and e). Experiments conducted in $0.2 \mathrm{~mol} \mathrm{~L}^{-1}$ of $\left(\mathrm{NH}_{4}\right)_{2} \mathrm{SO}_{4}$ solution, $\mathrm{pH} 3.5$. [foreign specie] $=0.1 \mu \mathrm{mol} \mathrm{L}{ }^{-1}$. $\mathrm{E}_{\text {dep }}=-0.5 \mathrm{~V} ; \mathrm{t}_{\text {dep }}=120 \mathrm{~s} ; \mathrm{f}=60 \mathrm{~Hz} ; \mathrm{A}_{\mathrm{p}}=0.025 \mathrm{~V}$ and $\mathrm{t}_{\text {eq }}=15 \mathrm{~s} ;$ potential range: -0.2 to $1.0 \mathrm{~V} v s$. $\mathrm{Ag} / \mathrm{AgCl}$. 
Table 2. Summary of results for copper fortification in biodiesel samples $(n=3)$

\begin{tabular}{lccc}
\hline Sample & {$\left[\mathrm{Cu}^{2+}\right]$ added $/\left(\mathrm{nmol} \mathrm{L}^{-1}\right)$} & {$\left[\mathrm{Cu}^{2+}\right]$ recovered $/\left(\mathrm{nmol} \mathrm{L}^{-1}\right)$} & Recovery $/ \%$ \\
\hline A1 & 10.0 & $9.7 \pm 0.1$ & $97.0 \pm 1.4$ \\
A2 & 25.0 & $25.7 \pm 1.2$ & $102.8 \pm 5.1$ \\
B1 & 10.0 & $11.1 \pm 0.2$ & $111.0 \pm 2.6$ \\
B2 & 25.0 & $27.4 \pm 0.6$ & $109.6 \pm 2.6$ \\
\hline
\end{tabular}

A: soybean biodiesel; B: babassu biodiesel.

Table 3. Comparison of different modified electrodes for copper determination in biodiesel matrices

\begin{tabular}{|c|c|c|c|c|c|c|}
\hline Electrode & Modifier & Technique & RSD / \% & $\mathrm{LOD} /\left(\mathrm{nmol} \mathrm{L}{ }^{-1}\right)$ & Linear range / $\left(\mathrm{nmol} \mathrm{L}^{-1}\right)$ & Reference \\
\hline GC & $\mathrm{Hg}$ film & $\mathrm{SCP}$ & 3.5 & 3.2 & $315-7868$ & 12 \\
\hline GC & Bi film & SWASV & - & 0.5 & $16-1574$ & 13 \\
\hline GC & $\mathrm{Hg}$ film & DPASV & 18.0 & 4.7 & $20-100$ & 14 \\
\hline SPGE & - & SWASV & $\begin{array}{l}1.6 \\
3.0\end{array}$ & $\begin{array}{l}7.9 \\
0.5\end{array}$ & $\begin{array}{l}315-4006 \\
315-4300\end{array}$ & 35 \\
\hline CPE & Vulcan-CBZ & SWASV & 2.2 & 1.2 & 6-190 & this work \\
\hline
\end{tabular}

GC: glassy-carbon; SPGE: screen-printed gold electrode; CPE: carbon paste electrode; SCP: stripping chronopotentiometry; DPASV: differential pulse anodic stripping voltammetry; SWASV: square wave anodic stripping voltammetry.

\section{Application of the sensor in fuel samples}

The CPE/Vulcan-CBZ sensor was applied for the determination of $\mathrm{Cu}^{2+}$ in biodiesel samples, using the two-level recovery study, as shown in Table 2, and the voltammograms of the analyzes of the fortified biodiesel samples and their respective standard addition curve are shown in Figures S2 and S3 (in the SI section). The average recovery varied between 97.0 and $102.8 \%$ for the soybean biodiesel samples and between 109.6 and $111.0 \%$ for the babassu biodiesel samples, confirming the applicability of the proposed electrode for biodiesel samples.

Table 3 presents the comparison of the proposed method with the literature data for determination of copper ions in biodiesel. It can be observed that CPE/VulcanCBZ presented one of the lowest detection limits, a wide linear range and a good relative standard deviation (RSD) compared to the other reported work, ${ }^{11,14,35}$ indicating that this method is an excellent alternative for the quantification of copper in fuel samples.

\section{Conclusions}

The proposed electrochemical sensor provided high sensitivity, good linearity, optimum oxidation peak definition, high reproducibility and low limits of detection and quantification, due to its chelate forming ability and high affinity of the Vulcan-CBZ material for copper ions. Although the sensor shows response to other metallic species, it can be observed that these do not significantly interfere in the copper response. The application of this electrode in biodiesel samples, showed good accuracy verified by the recovery studies. The easy preparation of the sample and the low cost appear as advantages to the existing procedures. In addition, the method proved to be simple, fast and inexpensive for implementation, compared to procedures presented in the literature, indicating that this sensor can be used as a viable alternative for determination of trace amounts of $\mathrm{Cu}^{2+}$ in fuel samples.

\section{Supplementary Information}

Supplementary information is available free of charge at http://jbcs.sbq.org.br as a PDF file.

\section{Acknowledgments}

The authors are grateful to Brazilian agencies CNPq, Capes and FAPEMA for fellowships and financial support.

\section{References}

1. Demirbas, A.; Energy Convers. Manage. 2008, 49, 2106.

2. Guo, D.; Pan, H.; Li, X.; Appl. Microbiol. Biotechnol. 2015, 18, 7805 .

3. Milano, J.; Ong, H. C.; Masjuki, H. H.; Chong, W. T.; Lam, M. K.; Loh, P. K.; Vellayan, V.; Renewable Sustainable Energy Rev. 2016, 58, 180.

4. Sarin, A.; Arora, R.; Singh, N. P.; Sarin, R.; Sharma, M.; Malhotra, R. K.; J. Oil Fat Ind. 2010, 87, 567. 
5. Knothe, G.; Dunn, R. O.; J. Am. Oil Chem. Soc. 2003, 80, 1021.

6. Antunes, G. A.; dos Santos, H. S.; da Silva, Y. P.; Silva, M. M.; Piatnicki, C. M. S.; Samios, D.; Energy Fuels 2017, 31, 2944.

7. Lima, A. S. S.; Rodrigues, S. M.; Korn, M. G. A.; Ribeiro, D. S. M.; Santos, J. L. M.; Teixeira, L. S. G.; Microchem. J. 2014, 117, 144.

8. Behbahani, M.; Akbari, A. A.; Amini, M. M.; Bagheri, A.; Anal. Methods 2014, 6, 8785.

9. Ghisi, M.; Chaves, E. S.; Quadros, D. P. C.; Marques, E. P.; Curtius, A. J.; Marques, A. L. B.; Microchem. J. 2011, 98, 62.

10. Lobo, F. A.; Goveia, D.; de Oliveira, A. P.; Pereira-Filho, E. R.; Fraceto, L. F.; Dias Filho, N. L.; Rosa, A. H.; Fuel 2009, 88, 1907.

11. Sanchez, R.; Sánchez, C.; Lienemann, C.-P.; Todolí, J.-L.; J. Anal. At. Spectrom. 2015, 30, 64.

12. Almeida, E. S.; Monteiro, M. A. N. A.; Montes, R. H. O.; Mosquetta, R.; Coelho, N. M. M.; Richter, E. M.; Muñoz, R. A. A.; Electroanalysis 2010, 22, 1846.

13. Pinto, L.; Lemos, S. G.; Microchem. J. 2013, 110, 417.

14. Martiniano, L. C.; Abrantes, V. R.; Yotsumoto Neto, S.; Marques, E. P.; Fonseca, T. C. O.; Paim, L. L.; Souza, A. G.; Stradiotto, N. R.; Aucélio, R. Q.; Cavalcante, G. H. R.; Marques, A. L. B.; Fuel 2013, 103, 1164.

15. Yotsumoto Neto, S.; Viegas, H. D. C.; Almeida, J. M. S.; Cavalheiro, E. T. G.; Araújo, A. S.; Marques, E. P.; Marques, A. L. B.; Electroanalysis 2015, 27, 1.

16. Tormin, T. F.; Narciso, L. C. D.; Richter, E. M.; Munoz, R. A. A.; Fuel 2014, 117, 952.

17. Almeida, E. S.; Richter, E. M.; Munoz, R. A. A.; Anal. Chim. Acta. 2014, 837, 38 .

18. Lowinsohn, D.; Bertotti, M.; Quim. Nova 2006, 29, 1318.

19. Dipti, S. S.; Chung, I.-C.; Chung, W. S.; Met. Mater. Int. 2007, $13,417$.

20. Bezerra, C. W. B.; Zhang, L.; Liu, H.; Lee, K.; Marques, A. L. B.; Marques, E. P.; Wang, H.; Zhang, J.; J. Power Sources 2007, $173,891$.
21. Tenório, R. P.; Góes, A. J. S.; de Lima, J. G.; de Faria, A. R.; Alves, A. J.; de Aquino, T. M.; Quim. Nova 2005, 28, 1030.

22. Sousa-Pereira, D.; Goulart, C. M.; dos Reis, C. M.; Echevarria, A.; Rev. Virtual Quim. 2013, 5, 770.

23. Afkhami, A.; Bagheri, H.; Khoshsafar, H.; Saber-Tehranic, M.; Tabatabaeed, M.; Shirzadmehra, A.; Anal. Chim. Acta 2012, 746, 98 .

24. Afkhami, A.; Ghaedi, H.; Madrakian, T.; Rezaeivala, M.; Electrochim. Acta 2013, 89, 377.

25. Afkhami, A.; Soltani-Felehgari, F.; Madrakian, T.; Ghaedi, H.; Rezaeivala, M.; Anal. Chim. Acta 2013, 771, 21.

26. Freitas, H. C.; Almeida, E. S.; Tormin, T. F.; Richter, E. M.; Munoz, R. A. A.; Anal. Methods 2015, 7, 7170.

27. O'Reilly, J. M.; Mosher, R. A.; Carbon 1983, 21, 47.

28. Silverstein, R. M.; Webster, F. X.; Kiemle, D. J.; Identificação Espectrométrica de Compostos Orgânicos; LTC: Rio de Janeiro, 2006.

29. Pandian, G. D.; Anbusrinivasan, P.; Mojumdar, S. C.; J. Therm. Anal. Calorim. 2015, 119, 845.

30. Manzanera-Estrada, M.; Ayala, L. F. H.; Osorio-Monreal, G.; García-Ramos, J. C.; Ortiz-Frade, L.; J. Mex. Chem. Soc. 2013, 57, 192.

31. Duarte, E. H.; Gorla, F. A.; Sartori, E. R.; Tarley, C. R. T.; Quim. Nova 2014, 37, 1496.

32. Gowda, J. I.; Nandibewoor, S. T.; Asian J. Pharm. Sci. 2014, 9,42 .

33. Agostinho, S. M. L.; Villamil, R. F. V.; Quim. Nova 2004, 27, 813.

34. Janegitz, B. C.; Marcolino Junior, L. H.; Fatibello-Filho, O.; Quim. Nova 2007, 30, 1673.

35. Tormin, T. F.; Oliveira, G. K. F.; Richter, E. M.; Munoz, R. A. A.; Electroanalysis 2016, 28, 940.

Submitted: July 21, 2017

Published online: October 10, 2017 